Article

\title{
External Pressure, Corporate Governance, and Voluntary Carbon Disclosure: Evidence from China
}

\author{
Pinglin He ${ }^{1,2}$, Huayu Shen ${ }^{1, *(\mathbb{D})}$, Ying Zhang ${ }^{1}$ and Jing Ren ${ }^{1}$ \\ 1 School of Economics and Management, North China Electric Power University, Beijing 102206, China; \\ xmu2017@hotmail.com (P.H.); duhb2013@126.com (Y.Z.); hinongwu@126.com (J.R.) \\ 2 Beijing Key Laboratory of New Energy and Low-Carbon Development, \\ North China Electric Power University, Changping, Beijing 102206, China \\ * Correspondence: shy1130@126.com; Tel.: +86-157-1136-4450
}

Received: 13 April 2019; Accepted: 19 May 2019; Published: 22 May 2019

\begin{abstract}
This paper uses manually collected data of carbon information disclosure for listed companies, from 2009 to 2015 in China, to measure corporate carbon information disclosure, and it explores the impact of external pressure and internal governance on carbon information disclosure through text analysis and a hierarchy analysis process. The results show that, firstly, the greater the external pressure is, the higher the level of carbon information disclosure will be; that is, when listed companies are state-owned enterprises or in heavy pollution industries, the level of carbon information disclosure is higher. Secondly, the higher the level of corporate governance is, the higher the level of carbon information disclosure will be; that is, when the board of directors is larger, the proportion of independent directors is higher, and the chairman and general manager positions are differentiated, the level of carbon information disclosure is higher. Furthermore, when listed companies are state-owned and in heavy pollution industries, the level of carbon information disclosure is higher; when the chairman and general manager are in the same position (lower governance level), the positive impact of government pressure on carbon disclosure is less significant, the positive impact of external pressure on carbon disclosure is less significant, and the positive interactive impact of government pressure and external pressure on carbon disclosure is less significant. The conclusions of this paper are still robust after Heckman two-stage regression, propensity score matching (PSM) analysis, sub-sample regression, and double clustering analysis.
\end{abstract}

Keywords: carbon information disclosure; analytic hierarchy process; internal governance; external pressure; state-owned enterprises; heavy polluting industries

JEL Classification: G30; G32; G34

\section{Introduction}

As the problem of climate warming caused by greenhouse gas emissions becomes more and more serious, how to deal with global change is becoming a global hot topic. At present, China's carbon dioxide emissions are at the top of the global rankings almost every year, which results in China facing enormous pressure to save energy and reduce emissions. Development of the Carbon Disclosure Project (CDP) witnessed the process of environmental information disclosure of Chinese companies. Since 2009, the CDP issued carbon information disclosure requests to the top 100 market value listed companies in China. The number of Chinese listed companies participating in the response ranged from nine in 2010 to 25 in 2017. With the promulgation of environmental information disclosure laws and regulations, and the gradual opening of the carbon market and green certificate market, in addition to Chinese A shares to be formally incorporated into the MSCI (Morgan Stanley Capital 
International) global index and emerging market index, Chinese listed companies are paying more and more attention to carbon information disclosure.

Carbon information, as part of environmental information, usually appears in environmental information reports. In China, carbon information is a voluntary disclosure item, whereby only a few listed companies disclose carbon information in the environmental information report. As non-financial information, carbon disclosure can reduce the degree of information asymmetry between listed companies and stakeholders, and then affect the company's financial decisions. In the literature, a few studies on corporate environmental information disclosure can be found. Zeng et al. took the Chinese manufacturing industry as a sample, and argued that firm size, ownership structure, and market level will affect the level of environmental information disclosure [1]. Some scholars found that listed companies in heavy pollution industries have a higher level of environmental information disclosure [2]. At the same time, the promulgation of laws and regulations, as well as executive turnover, will also affect the level of environmental information disclosure [3,4]. Yao and Liang argued that the further away a company is from a political center or environmental supervision, the lower the level of environmental disclosure will be [5]. Shaukat et al. considered that board characteristics are important factors affecting corporate environmental information disclosure [6]. Cheng et al. found that there is a significant negative correlation between corporate political connections and environmental information disclosure [7]. A few studies on carbon information disclosure can also be found. Li et al. showed that media coverage and carbon information disclosure can reduce financing costs [8]. Qian and Schaltegger discussed the impact of carbon information disclosure on corporate performance from the perspective of organizational legitimacy theory [9]. Kalu et al. argued that social and financial market were critical determinant factors for carbon disclosure, while the economic and institutional factors did not achieve a significant effect on voluntary carbon disclosure [10]. Grauel and Gotthardt studied the influencing factors of carbon information disclosure in different countries [11]. Matsumura et al. found that carbon emissions and carbon disclosure level will affect the value of a company. Most of the current research is based on the capital market of developed countries or CDP data, while there is less research based on carbon disclosure data of listed companies in developing countries [12].

This paper collects carbon information disclosure data of listed companies in China from 2009 to 2015, measures the level of carbon information disclosure by qualitative and quantitative methods, and studies the influencing factors of carbon information disclosure level for the listed companies based on organizational legitimacy theory and governance theory. China is one of the top 10 countries with the largest carbon emissions in the world. This paper studies the factors affecting the carbon emissions of listed companies in China, and provides relevant recommendations for listed companies to reduce carbon emissions, thereby achieving China's energy conservation and emission reduction targets.

There are three major contributions of this paper. Firstly, based on the collected data and stakeholders and organizational legitimacy theory, this paper brings external pressure and internal governance into the research framework to study their impacts on the level of corporate carbon information disclosure, which provides a new framework for the influencing factors of carbon information disclosure of listed companies. Secondly, as there is no unified measurement for carbon information disclosure of listed companies in China, the quantification of its measurement index is still in the exploratory stage. This paper uses text analysis and the analytic hierarchy process (AHP) to quantify the carbon information disclosure level of listed companies in China, which provides a new way to measure the carbon disclosure level of listed companies for future studies. Thirdly, this paper explores whether external pressure and internal governance interact with the carbon information disclosure of listed companies in China. The conclusions can provide a scientific basis for regulatory policy-making within listed companies to improve the level of carbon information disclosure, while also enriching the literature of stakeholder theory. Stakeholder theory emphasizes that enterprise management is a management activity to balance the interests of all stakeholders. Compared with the traditional shareholder supremacy theory, the theory holds that the development of any enterprise cannot be separated from the input or participation of various stakeholders. The enterprise pursues 
the overall interests of stakeholders, not just the interests of certain subjects. In fact, carbon emission information will have an impact on the interests of some important stakeholders in the enterprise. For example, the introduction or adjustment of environmental protection policies will have a direct impact on the economic interests of shareholders and creditors of some polluting enterprises. Senior managers of enterprises need to make emission reduction decisions in order to meet the needs of environmental supervision policies, and they also have a corresponding demand for information on the status of carbon emissions of enterprises and industries. Enterprises will emit greenhouse gases such as carbon dioxide in production process; thus, the health of nearby residents will be impacted, as will that of the majority of residents of the enterprises.

The paper is organized as follows: Section 2 presents a literature review on external pressure, internal governance, and corporate carbon information disclosure, and puts forward the research hypotheses. Section 3 defines the variables and presents the research model. Section 4 presents the empirical results and analyses. In Section 5, robustness tests are presented. The final section presents the conclusions and implications.

\section{Literature Review and Research Hypotheses}

\subsection{External Pressure and Corporate Carbon Information Disclosure}

Organizational legitimacy theory holds that an enterprise, as a social organization, has an implicit social contract with other stakeholders. The "legality mechanism" refers to the power of ideas that induce or force organizations to adopt organizational structures and behaviors that have legitimacy. The basic idea of the legality mechanism is that the social legal system, cultural expectations, and conceptual systems are now widely accepted social facts, with strong binding forces and regulating people's behavior [13]. As an important stakeholder of enterprises, the government and the public have an environmental contract with enterprises, which is of great significance to the use of pollutant emission information and information decision-making of enterprises. The study of whether the external pressure they convey is conducive to improving the level of corporate carbon emission information disclosure is particularly important. If the enterprise cannot meet the requirements of the implicit social contract, it cannot guarantee the legitimacy of its operation; thus, it is difficult to survive and develop. Therefore, managers will choose to disclose carbon information in order to deal with public pressure caused by implicit contracts so as to show the legitimacy of their operations to the public [14].

Through reviewing the existing literature, it could be found that the research on carbon information disclosure mainly focused on the ways and conditions of disclosure. Most of the research on the influencing factors of carbon information disclosure of enterprises was from the perspective of corporate characteristics and governance structure, and less consideration was given to the impact of public pressure exerted by stakeholders on carbon information disclosure. In fact, stakeholders are closely related to the survival and development of enterprises, and the public pressure they exert on enterprises is likely to have an impact on corporate carbon information disclosure. External pressure mainly comes from creditors, government, the media, and society. Creditors pay attention to the environmental protection information of enterprises to determine whether to grant loans to enterprises; the government punishes enterprises with administrative penalties for failing to comply with relevant laws and regulations on environmental protection; the media uses public opinion reports as a means of monitoring enterprises to fulfill relevant environmental responsibilities; lastly, good social reputation helps enterprises win the trust of consumers, thereby enabling enterprises to benefit from increasingly fierce competition. More importantly, because of the different nature of the ultimate control right, companies may behave differently under different pressures. According to the ultimate control right, companies can be divided into state-owned enterprises and non-state-owned enterprises. The impact of public pressure on carbon information disclosure differs between state-owned enterprises and 
non-state-owned enterprises. This is also a situation that researchers in the existing literature did not take into account.

The public pressure of companies comes mainly from the government, shareholders, and so on. Requiring firms to disclose carbon information is an important measure for the government to implement environmental protection policies and protect the ecological environment. Since 1979, the Chinese government promulgated the "Environmental Protection Law", "Water Pollution Prevention Law", "Air Pollution Protection Law", and other relevant laws and regulations. In June 2012, the National Development and Reform Commission issued the "Interim Measures on the Management of Voluntary Greenhouse Gas Emission Reduction Transactions". In addition, the regulations of the Ministry of Finance on the disclosure of firm environmental information mainly include the "Firm Accounting System", "Accounting Standards for Firms-Contingent Events", "Auditing Standards for Certified Public Accountants No.1631-Consideration of Environmental Matters in the Audit of Financial Statements", etc. At the same time, the China Bank Regulatory Commission (CBRC) issues the "Green Credit Guidelines" to require banks to give full leverage to promote energy conservation, carbon emission reduction, and environmental protection. Additionally, "green credit", "green insurance", "green securities", and other laws and regulations were promulgated one after the other. A series of laws and regulations promulgated by the government and regulatory departments will undoubtedly bring pressure on carbon information disclosure for firms. "The List of Environmental Protection Inspection Industry Classified Management of Listed Companies" promulgated in 2008 clearly defines which industries are heavy polluting. The China Securities Regulatory Commission (CSRC) has more stringent requirements on environmental information disclosure of listed companies in heavy polluting industries. Therefore, the heavy polluting industries are more willing to disclose carbon information when facing the pressure of laws and regulations.

To summarize, the below hypothesis is proposed.

Hypothesis (H1). The carbon disclosure level of listed companies in heavy polluting industries is even higher.

In China, in addition to pursuing the goal of maximizing profits, state-owned enterprises also have to shoulder a lot of social responsibilities. Therefore, after the government promulgates environmental policies, state-owned enterprises are under pressure from the government and will assume more environmental responsibilities, including carbon disclosure. In state-owned enterprises, due to the constraints of policy burden, the impact of executive characteristics on the company is limited. Girma et al. argued that the bureaucratic structure of state-owned enterprises improves the company's environmental information disclosure level, because the state-owned enterprises are constrained by many aspects such as the state system or political burden [15]. Based on the above analysis, the below assumption is made.

Hypothesis (H2). Listed companies of state-owned firms have a higher level of carbon information disclosure.

\subsection{The Internal Governance and the Corporate Carbon Information Disclosure}

Corporate governance is an important mechanism to resolve the separation of ownership and control rights and to protect the interests of external investors. A large number of previous studies showed that internal governance is an important factor affecting the quality of firm information disclosure, including the size of the board of directors, the proportion of independent directors, and the two-in-one nature of the chairman and general manager position [16]. Some studies found that a larger board of directors and a higher proportion of independent directors, a higher level of internal governance of the company, and a lower level of internal governance of the company when the chairman of the board of directors and the general manager are in the same position all affect the quality of firm information disclosure. Shaukat et al. indicated that the larger the board of directors is, and the higher the level of corporate governance is, the higher the level of company information 
disclosure will be [6]. Fodio and Oba believed that the stronger the independence of the board is, the higher the level of information disclosure of the company will be [17]. Kolk et al. found that the more serious the agency problem is within the company, the more capable and motivated the manager will be to infringe on shareholders' interests and whitewash financial reports, and the more capable and motivated the manager will be to hide important financial information from competitors for rent-seeking, thereby reducing the quality of accounting information [18]. To sum up, the higher the level of internal governance is, the higher the level of carbon information disclosure will be. Based on the above analysis, this paper puts forward the assumptions below.

Hypothesis (H3). The larger the size of the board is, the higher the carbon information disclosure level of the company will be.

Hypothesis (H4). The higher the proportion of independent directors is, the higher the level of carbon information disclosure will be.

Hypothesis (H5). When the two duties of chairman and general manager are unified, the level of carbon information disclosure will be lower.

\subsection{Interaction between External Pressure and Internal Governance on Carbon Information Disclosure}

The greater the external pressure is, the higher the level of carbon information disclosure will be. However, when there are differences in corporate governance, the positive impact of external pressure on corporate carbon disclosure level may be different. When the corporate governance level is high, the corporate management response to external pressure is more timely; thus, the level of corporate carbon information disclosure may be higher. On the other hand, when the corporate governance level is low, the corporate management response to external pressure may be inadequate; thus, the level of carbon disclosure may be lower. Based on this, the below assumption is made.

Hypothesis (H6). The higher the corporate governance level is, the more obvious the positive impact of external pressure will be on the level of corporate carbon information disclosure.

\section{Research Model and Variable Definitions}

\subsection{Sample Selection and Data Sources}

This paper used a sample of Chinese listed companies from 2009 to 2015. The selection process was as follows: firstly, special treatment (ST) or *ST companies and financial and insurance companies were eliminated; secondly, companies with missing data were eliminated. The final sample included 13,540 firm-year observations. We manually collected carbon information disclosure data from firm environment reports. All the other data in this article were obtained from the WIND Information Technology Corporation database and the China Stock Market and Accounting Research (CSMAR) database. To eliminate the influence of outliers, we carried out the tail treatment of continuous variables at $1 \%$ and $99 \%$ levels.

\subsection{Variable Definitions}

\subsubsection{Measurement of Carbon Information Disclosure Level}

This paper used CDI1 and CDI2 to denote the level of carbon information disclosure. CDI1 quantified whether carbon information was disclosed, with an assignment value of 1 or 0 , determining the disclosure level using the analytic hierarchy process. CDI2 categorized carbon information as being quantized (2), non-quantized (1), or lacking (0), determining the disclosure level using the analytic hierarchy process. 
The carbon information disclosure was collected and measured based on several factors. Based on the description of carbon information disclosure in the CDP (Carbon Disclosure Project), CDSB (Climate Disclosure Standards Board), and CRDI (Climate Risk Disclosure Initiative) documents, this paper evaluated China's carbon information through text analysis and content related to carbon information, in addition to the actual description of Chinese listed companies in the environmental report section of the corporate social responsibility report. It was divided into six aspects, including carbon emission reduction objectives and strategies, carbon emission reduction management, carbon emission reduction accounting, carbon emission reduction performance, financial input and government subsidies, and environmental accidents, before being refined into 15 secondary indicators, as shown in Table 1 .

Table 1. Levels and indicators of carbon information disclosure.

\begin{tabular}{|c|c|c|}
\hline First Level Index $(\mathrm{T})$ & Second Level Index (I) & Indicators \\
\hline \multirow[t]{2}{*}{$\begin{array}{l}\text { Carbon reduction } \\
\text { targets and strategies }\end{array}$} & Carbon reduction targets & $\begin{array}{l}\text { 1. Firm should formulate clear and effective emission reduction targets } \\
\text { 2. Planning and risk measures for future low-carbon development } \\
\text { 3. Energy saving and emission reduction-related notes } \\
\text { and commitments }\end{array}$ \\
\hline & Carbon reduction & $\begin{array}{l}\text { 1. Long- and short-term strategies launched by the company } \\
\text { 2. Development of incentive mechanism, encouraging objects } \\
\text { and methods }\end{array}$ \\
\hline \multirow{4}{*}{$\begin{array}{l}\text { Carbon emission } \\
\text { reduction } \\
\text { management }\end{array}$} & Institution setting & $\begin{array}{l}\text { The establishment of environmental protection, energy conservation, } \\
\text { and emission reduction institutions and an information system for the } \\
\text { management platform }\end{array}$ \\
\hline & Internal training & $\begin{array}{l}\text { Education and training in environmental awareness and related skills } \\
\text { for management and staff }\end{array}$ \\
\hline & $\begin{array}{l}\text { Identification and trading } \\
\text { of carbon emissions }\end{array}$ & $\begin{array}{l}\text { 1. Certification/verification status of carbon emissions or energy saving, } \\
\text { environmental assessment, etc. } \\
\text { 2. Companies involved in carbon emission reduction transactions }\end{array}$ \\
\hline & $\begin{array}{l}\text { Carbon emission reduction } \\
\text { activities }\end{array}$ & $\begin{array}{l}\text { Promotion and publicity of energy conservation and environmental } \\
\text { protection knowledge, afforestation, environmental protection } \\
\text { donations, and other activities }\end{array}$ \\
\hline \multirow{2}{*}{$\begin{array}{l}\text { Carbon emission } \\
\text { reduction accounting }\end{array}$} & Energy consumption & Consumption of fuel, electricity, heat, gas, and refrigerating capacity \\
\hline & Carbon footprint & $\begin{array}{l}\text { Emission of air pollutants such as carbon dioxide, sulfides, nitrogen } \\
\text { oxides, and dust }\end{array}$ \\
\hline \multirow{3}{*}{$\begin{array}{l}\text { Carbon emission } \\
\text { reduction } \\
\text { performance }\end{array}$} & $\begin{array}{l}\text { Energy saving and } \\
\text { emission reduction }\end{array}$ & $\begin{array}{l}\text { Compared with the previous year, the company's carbon emissions or } \\
\text { joint energy }\end{array}$ \\
\hline & Standard degree & $\begin{array}{l}\text { In terms of energy saving and emission reduction, the company meets } \\
\text { the requirements of government standards and the achievement of } \\
\text { carbon reduction targets }\end{array}$ \\
\hline & Benefit estimation & $\begin{array}{l}\text { The company reduces the benefits of carbon emissions, such as cost } \\
\text { saving, greening rate, air quality, and so on }\end{array}$ \\
\hline \multirow{3}{*}{$\begin{array}{l}\text { Capital investment } \\
\text { and government } \\
\text { subsidy }\end{array}$} & Low-carbon investment & $\begin{array}{l}\text { The company's low-carbon economy development-related technology } \\
\text { and capital investment and research results, such as fixed assets } \\
\text { investment, technological transformation, research and development } \\
\text { (R\&D) investment, etc. }\end{array}$ \\
\hline & Expense expenditure & $\begin{array}{l}\text { Sewage charges, daily maintenance costs, and environmental protection } \\
\text { greening investment }\end{array}$ \\
\hline & $\begin{array}{l}\text { Government and social } \\
\text { grants and incentives }\end{array}$ & $\begin{array}{l}\text { Project investment, energy saving, and emission reduction subsidies } \\
\text { and incentive funds }\end{array}$ \\
\hline $\begin{array}{l}\text { Environmental } \\
\text { accident }\end{array}$ & $\begin{array}{l}\text { Government penalties and } \\
\text { pollution incidents }\end{array}$ & $\begin{array}{l}\text { Environmental pollution and damage incidents, illegal incidents, } \\
\text { departures by environmental protection departments or lists of key } \\
\text { pollution enterprises, and fines and compensation paid for them }\end{array}$ \\
\hline
\end{tabular}

We conducted a text analysis of the environmental part of the CSRC report. According to the 15 secondary indicators in the report, we scored the indicators as being without description, with qualitative description, or with quantitative description.

At the same time, we tested the reliability of the scoring results, using five independent scoring methods. In the reliability test, the Kendall coefficient was 0.95 , the chi-square value was 36.1 , and the 
probability level was less than 0.05 . The significance test showed that the results of text analysis in this paper have high reliability and can be used for follow-up research.

After scoring the indicators, this paper used the analytic hierarchy process to get the annual carbon information disclosure quality score of each company. Detailed steps are shown in Tables A1-A8 (Appendix A).

\subsubsection{Measurement of External Pressure}

In this paper, two indicators were used to measure external pressure, including whether companies were state-owned enterprises and whether they were heavy polluting industries. The list of "Environmental Protection Inspection Industry Classified Management of Listed Companies" promulgated in 2008 clearly defines which industries are heavy polluting. Heavy polluting industries include thermal power, steel, cement, electrolytic aluminum, coal, metallurgy, building materials, mining, chemical, petrochemical, pharmaceutical, light industry brewing, paper, fermentation, textile, leather making, and so on. GP represents the dummy variable of government pressure. When the company is state-owned, the value is 1 ; otherwise, the value is 0 . POLU represents the dummy variable of external pressure. When the company is in a heavy pollution industry, the value is 1 ; otherwise, the value is 0 .

\subsubsection{Measurement of Internal Governance Level}

This paper used three indicators to measure the level of internal governance, including the size of the board of directors, the proportion of independent directors, and the integration of the chairman and the general manager. BOARD represents the size of the board, whereby the total number of directors was taken as a logarithm. INDEP represents the proportion of independent directors, calculated using the number of independent directors divided by the total number of board members. DUAL represents the duality of the chairman and general manager positions.

\subsubsection{Other Control Variables}

Referring to previous research on the influencing factors of carbon information disclosure and environment information disclosure [19], this study included the following control variables: size of the company (SIZE), fixed assets ratio (FIXA), return on assets (ROA), cash holding level (CASH), market-to-book ratio (M/B), asset liability ratio (LEV), firm age (AGE), whether the company faced four major audits (BIG4), and the shareholding ratio of the largest shareholder (FIRST).The variable definition of this paper is shown in Table 2.

Table 2. Definition of variables.

\begin{tabular}{|c|c|c|c|}
\hline Variables & Name & Symbol & Definition \\
\hline \multirow{2}{*}{$\begin{array}{l}\text { Dependent } \\
\text { Variables }\end{array}$} & CDI1 & & $\begin{array}{l}\text { Carbon information disclosed }=1 \text {; carbon information not disclosed }=0 \text {; } \\
\text { quantified using the analytic hierarchy process }\end{array}$ \\
\hline & CDI2 & & $\begin{array}{l}\text { Quantized carbon information }=2 \text {; non-quantized carbon information }=1 \text {; } \\
\text { lack of carbon information }=0 \text {; disclosure level quantified using the analytic } \\
\text { hierarchy process }\end{array}$ \\
\hline \multirow{5}{*}{$\begin{array}{l}\text { Independent } \\
\text { Variables }\end{array}$} & GP & + & $\begin{array}{l}\text { Dummy variable of government pressure; state-owned }=1 ; \\
\text { non-state-owned = }\end{array}$ \\
\hline & POLU & + & $\begin{array}{l}\text { Dummy variable of external pressure; company in heavy pollution industry } \\
1=1 \text {; company not in heavy pollution industry }=0\end{array}$ \\
\hline & BOARD & + & The size of the board, with the total number of directors taken as a logarithm. \\
\hline & INDEP & + & $\begin{array}{l}\text { The proportion of independent directors, with the number of independent } \\
\text { directors divided by the total number of board members }\end{array}$ \\
\hline & DUAL & - & Duality of the chairman and general manager positions \\
\hline
\end{tabular}


Table 2. Cont.

\begin{tabular}{|c|c|c|c|}
\hline Variables & Name & Symbol & Definition \\
\hline \multirow{11}{*}{$\begin{array}{c}\text { Control } \\
\text { Variables }\end{array}$} & SIZE & + & The size of a company, taken as a logarithm of total assets \\
\hline & FIXA & + & Fixed assets ratio, taken as fixed assets divided by total assets \\
\hline & ROA & $+/-$ & Return on assets, taken as net profit divided by average total assets \\
\hline & CASH & + & Cash holding level, taken as net cash flow divided by average total assets \\
\hline & $\mathrm{M} / \mathrm{B}$ & $+/-$ & Market-to-book ratio, taken as market value divided by shareholders' equity \\
\hline & LEV & + & Asset liability ratio, taken as total liabilities divided by total assets \\
\hline & AGE & $+/-$ & Firm age, The year minus initial public offering time \\
\hline & BIG4 & + & Whether the company faced four major audits; yes $=0 ;$ no $=0$ \\
\hline & FIRST & $+/-$ & Shareholding ratio of the largest shareholder \\
\hline & Year & & Year controlled \\
\hline & Ind & & Industry controlled \\
\hline
\end{tabular}

1 "The List of Environmental Protection Inspection Industry Classified Management of Listed Companies" promulgated in 2008 clearly defines which industries are heavy polluting. Heavy polluting industries include thermal power, steel, cement, electrolytic aluminum, coal, metallurgy, building materials, mining, chemical, petrochemical, pharmaceutical, light industry brewing, paper, fermentation, textile, leather making, and so on.

\subsection{Research Model}

To verify hypotheses $\mathrm{H} 1$ and $\mathrm{H} 2$, the following panel regression model was adopted:

$$
C D I 1_{t+1}\left(C D I 2_{t+1}\right)=\alpha+\beta_{1} * G P_{t}+\beta_{2} * P O L U_{t}+\beta_{3} * \text { control }_{t}+Y E A R+I N D+\varepsilon
$$

where CDI1 and CDI2 represent the level of carbon information disclosure. GP is the dummy variable of government pressure, POLU is the dummy variable of external pressure, the control represents the lagged control variables, and YEAR and IND represent the dummy variables for year and industry, respectively. According to hypotheses $\mathrm{H} 1$ and $\mathrm{H} 2, \beta_{1}$ and $\beta_{2}$ should be positive.

To verify hypotheses $\mathrm{H} 3, \mathrm{H} 4$, and $\mathrm{H} 5$, the following panel regression model was adopted:

$$
C D I 1_{t+1}\left(C D I 2_{t+1}\right)=\alpha+\beta_{1} * B O A R D_{t}+\beta_{2} * I N D E P_{t}+\beta_{3} * D U A L_{t}+\beta_{4} * \text { control }_{t}+Y E A R+I N D+\varepsilon,
$$

where GP is a dummy variable (state-owned enterprises $=1$; non-state-owned enterprises $=0$ ). All other variables are consistent with Equation (1), According to hypotheses $\mathrm{H} 3$ and $\mathrm{H} 4, \beta_{1}$ and $\beta_{2}$ should be positive. According to hypothesis $\mathrm{H} 5, \beta_{3}$ should be negative.

To verify hypothesis $\mathrm{H} 6$, the following panel regression model was adopted:

$$
\begin{gathered}
C D I 1_{t+1}\left(C D I 2_{t+1}\right)=\alpha+\beta_{1} * G P_{t}+\beta_{2} * P O L U_{t}+\beta_{3} * D U A L_{t}+\beta_{4} * G P_{t} * P O L U_{t} \\
+\beta_{5} * G P_{t} * D U A L_{t}+\beta_{6} * \text { POLU }_{t} * D U A L_{t}+\beta_{7} * G P_{t} * P O L U_{t} * D U A L_{t} \\
+\beta_{8} * \text { control }_{t}+Y E A R+I N D+\varepsilon
\end{gathered}
$$

where all variables are consistent with Equation (1).

\section{Empirical Results}

\subsection{Descriptive Statistics}

The results of the descriptive statistics are shown in Table 3. The minimum and maximum values of the dependent variable CDI1 were 0 and 0.415 , respectively; the mean value was 0.031 . The minimum and maximum values of the dependent variable CDI 2 were 0 and 0.810 , respectively; the mean value was 0.057 . The results show that the voluntary disclosure level of listed companies is relatively low in China, which is similar to the findings in previous studies [20]. The mean values of the independent variables GP and POLU were 0.400 and 0.384 , respectively, showing that, among 
listed companies, state-owned enterprises account for about $40 \%$, and heavy polluting enterprises account for about $38.4 \%$. The mean values of the independent variables BOARD, INDEP, and DUAL were $8.871,0.370$, and 0.227 , respectively. The maximum and minimum values, the quantile values, the standard deviations, and the mean values of other variables were all within reasonable limits.

Table 3. Results of descriptive statistics.

\begin{tabular}{ccccccccc}
\hline Variable & $\boldsymbol{N}$ & Mean & SD & Min & P25 & P50 & P75 & Max \\
\hline CDI1 & 13,540 & 0.031 & 0.089 & 0 & 0 & 0 & 0 & 0.415 \\
CDI2 & 13,540 & 0.057 & 0.172 & 0 & 0 & 0 & 0 & 0.810 \\
GP & 13,540 & 0.400 & 0.490 & 0 & 0 & 0 & 1 & 1 \\
POLU & 13,540 & 0.384 & 0.486 & 0 & 0 & 0 & 1 & 1 \\
BOARD & 13,540 & 8.871 & 1.756 & 5 & 8 & 9 & 9 & 15 \\
INDEP & 13,540 & 0.370 & 0.052 & 0.250 & 0.333 & 0.333 & 0.400 & 0.556 \\
DUAL & 13,540 & 0.227 & 0.419 & 0 & 0 & 0 & 0 & 1 \\
SIZE & 13,540 & 21.760 & 1.225 & 18.740 & 20.910 & 21.620 & 22.440 & 25.250 \\
FIXA & 13,540 & 0.237 & 0.173 & 0.002 & 0.101 & 0.202 & 0.341 & 0.757 \\
ROA & 13,540 & 0.038 & 0.060 & -0.332 & 0.013 & 0.035 & 0.065 & 0.215 \\
CASH & 13,540 & -0.151 & 0.369 & -1.436 & -0.310 & -0.112 & 0.041 & 1.374 \\
M/B & 13,540 & 2.213 & 2.023 & 0.204 & 0.919 & 1.621 & 2.755 & 11.530 \\
LEV & 13,540 & 0.458 & 0.237 & 0.047 & 0.279 & 0.453 & 0.624 & 1.696 \\
AGE & 13,540 & 9.541 & 6.179 & 0 & 4 & 10 & 15 & 25 \\
BIG4 & 13,540 & 0.028 & 0.165 & 0 & 0 & 0 & 0 & 1 \\
FIRST & 13,540 & 0.361 & 0.153 & 0.090 & 0.236 & 0.342 & 0.472 & 0.750 \\
\hline
\end{tabular}

\subsection{Results of Pearson and Spearman Correlation Coefficients}

Table 4 shows the correlations among dependent variables, independent variables, and control variables. The results show that CDI1 and CDI2 were significantly positively correlated with GP, POLU, BOARD, and INDEP at the 0.01 level of significance, and they were significantly negatively correlated with DUAL at the 0.01 level of significance. Thus, external pressure and internal governance level positively influence carbon information disclosure when other factors are not considered, basically confirming hypotheses $\mathrm{H} 1, \mathrm{H} 2, \mathrm{H} 3, \mathrm{H} 4$, and $\mathrm{H} 5$. All other variables were significantly correlated with CDI1 and CDI2.

\subsection{T-Test and Wilcox Test}

Table 5 shows the result of the $T$-test and Wilcox test between the heavy polluting industry sample and the non-heavy polluting industry sample. Panel A shows the T-test and Wilcox test results of CDI1 and CDI2 between POLU $=0$ and POLU $=1$. The results show that, compared with the non-heavy polluting industry sample, the mean and median values of CDI1 and CDI2 were higher in the heavy polluting industry sample, and there was a significant difference at the 0.01 level, consistent with hypothesis H2. Panel B shows the T-test and Wilcox test results of all independent variables and control variables. The results show that the mean and median values of all control variables were significantly different between the two groups. 
Table 4. Pearson and Spearman correlation coefficients.

\begin{tabular}{|c|c|c|c|c|c|c|c|c|c|c|c|c|c|c|c|c|}
\hline & CDI1 & CDI2 & GP & POLU & BOARD & INDEP & DUAL & SIZE & FIXA & ROA & CASH & $\mathbf{M} / \mathbf{B}$ & LEV & AGE & BIG4 & FIRST \\
\hline CDI1 & 1 & $1.000 * * *$ & $0.184^{* * *}$ & $0.103 * * *$ & $0.151^{* * *}$ & 0.009 & $-0.092 * * *$ & $0.342 * * *$ & $0.104^{* * *}$ & $0.045^{* * *}$ & $0.023 * *$ & $-0.198 * * *$ & $0.096 * * *$ & $0.088^{* * *}$ & $0.187 * * *$ & $0.122 * * *$ \\
\hline CDI2 & $0.998^{* * *}$ & 1 & $0.184^{* * *}$ & $0.103 * * *$ & $0.151 * * *$ & 0.009 & $-0.092 * * *$ & $0.342 * * *$ & $0.104^{* * *}$ & $0.045^{* * *}$ & $0.023 * *$ & $-0.198 * * *$ & $0.096^{* * *}$ & $0.088^{* * *}$ & $0.187 * * *$ & $0.122 * * *$ \\
\hline GP & $0.196^{* * *}$ & $0.198 * * *$ & 1 & $0.051^{* * *}$ & $0.228 * * *$ & $-0.045^{* * *}$ & $-0.258 * * *$ & $0.326 * * *$ & $0.136^{* * *}$ & $-0.151^{* * *}$ & $0.078^{* * *}$ & $-0.308^{* * *}$ & $0.295 * * *$ & $.377 * * *$ & $0.111 * * *$ & $0.211 * * *$ \\
\hline POLU & $0.118^{* * *}$ & $0.118^{* * *}$ & $.0512 * * *$ & 1 & $0.101^{* * *}$ & $-0.047^{* * *}$ & $-0.033 * * *$ & $0.059^{* * *}$ & $0.398 * * *$ & $-0.022 *$ & $0.103^{* * *}$ & $-0.036^{* * *}$ & 0.004 & $0.026 * *$ & 0.015 & $0.033 * * *$ \\
\hline BOARD & $0.173^{* * *}$ & $0.172 * * *$ & $0.242 * * *$ & $0.100 * * *$ & 1 & $-0.445 * * *$ & $-0.181 * * *$ & $0.270^{* * *}$ & $0.149 * * *$ & 0.001 & 0.015 & $-0.190 * * *$ & $0.154^{* * *}$ & $0.095 * * *$ & $0.088^{* * *}$ & 0.006 \\
\hline DUAL & $-0.094^{* * *}$ & $-0.094^{* * *}$ & $-0.258^{* * *}$ & $-0.033^{* * *}$ & $-0.170^{* * *}$ & $0.092 * * *$ & 1 & $-0.173^{* * *}$ & $-0.080^{* * *}$ & $0.070^{* * *}$ & $-0.058^{* * *}$ & $0.166^{* * *}$ & $-0.161^{* * *}$ & $-0.223 * * *$ & $-0.038^{* * *}$ & $-0.053^{* * *}$ \\
\hline SIZE & $0.391 * * *$ & $0.390 * * *$ & $0.330 * * *$ & $0.060^{* * *}$ & $0.307^{* * *}$ & $0.022 * *$ & $-0.166^{* * *}$ & 1 & $0.061^{* * *}$ & -0.009 & $-0.134 * * *$ & $-0.606^{* * *}$ & $0.413^{* * *}$ & $0.236 * * *$ & $0.211^{* * *}$ & $0.243^{* * *}$ \\
\hline FIXA & $0.131 * * *$ & $0.132 * * *$ & $0.173^{* * *}$ & $0.374 * * *$ & $0.167^{* * *}$ & $-0.053^{* * *}$ & $-0.096 * *$ & $0.116^{* * *}$ & 1 & $-0.161^{* * *}$ & $0.194 * * *$ & $-0.119^{* * *}$ & $0.075 * * *$ & $0.035^{* * *}$ & $0.059 * * *$ & $0.038^{* * *}$ \\
\hline $\mathrm{ROA}$ & $0.035^{* * *}$ & $0.034^{* * *}$ & $-0.107^{* * *}$ & -0.012 & & $-0.018^{*}$ & $0.043^{* * *}$ & $0.063^{* * *}$ & -0.163 & 1 & $0.037 * * *$ & $0.366 * * *$ & -0.431 *** & $-0.232 * * *$ & 0.001 & $0.086 * * *$ \\
\hline CASH & 0.012 & 0.012 & $0.0520 * * *$ & $0.094 * * *$ & 0.015 & $-0.023 * *$ & $-0.045^{* * *}$ & $-0.139 * * *$ & $0.173^{* * *}$ & $0.045^{* * *}$ & 1 & $0.098^{* * *}$ & $-0.142 * * *$ & $0.165^{* * *}$ & 0.010 & $-0.020 *$ \\
\hline $\mathrm{M} / \mathrm{B}$ & $-0.157 * * *$ & $-0.157 * * *$ & $-0.240^{* * *}$ & $-0.040^{* * *}$ & $-0.178^{* * *}$ & $0.053^{* * *}$ & 0.12 & $-0.508^{* * *}$ & $-0.149 * * *$ & $0.180^{* * *}$ & $0.113^{* * *}$ & 1 & -0.566 *** & $-0.244^{* * *}$ & $-0.122 * * *$ & $-0.130^{* * *}$ \\
\hline AGE & $0.084^{* * *}$ & $0.085 * * *$ & 0.376 * & $0.023 * *$ & $0.094^{* * *}$ & $-0.035 * * *$ & $-0.220^{* * *}$ & & **** & $-0.170^{* * *}$ & $0.117^{* * *}$ & $-0.125^{* * *}$ & $386 * * *$ & 1 & -0.006 & $-0.105^{* * *}$ \\
\hline BIG4 & $0.223 * * *$ & *** & & 0. & 0 & & -0 & & *** & 0.0 & 0. & -0 & $0.062 * * *$ & -0.009 & 1 & $0.086^{* * *}$ \\
\hline FIRST & $0.148 * * *$ & $0.151^{* * *}$ & $0.208^{* * *}$ & $0.030^{* * *}$ & 0.024 ** & $0.050 * * *$ & $-0.059 * * *$ & $0.279 * * *$ & $0.041^{* * *}$ & $0.099 * * *$ & $-0.036^{* * *}$ & $-0.124 * * *$ & $0.023 * *$ & $-0.094^{* * *}$ & $0.082 * * *$ & 1 \\
\hline
\end{tabular}

Note: The lower left triangle represents the Pearson correlation coefficient, while the upper right triangle represents the Spearman correlation coefficients. Significance levels of $10 \%, 5 \%$, and $1 \%$ are denoted by ${ }^{* * *}$, and ${ }^{* * *}$, respectively.

Table 5. Result of T-test and Wilcox test.

\begin{tabular}{|c|c|c|c|c|c|c|c|c|}
\hline \multirow{2}{*}{ NAME } & \multicolumn{3}{|c|}{ Non-Heavy Polluting Industry } & \multicolumn{3}{|c|}{ Heavy Polluting Industry } & \multirow{2}{*}{$\begin{array}{c}\text { Mean Difference } \\
(T \text {-Test })\end{array}$} & \multirow{2}{*}{$\begin{array}{l}\text { Median Difference } \\
\text { (Wilcox-Test) }\end{array}$} \\
\hline & $N$ & Mean & Median & $N$ & Mean & Median & & \\
\hline \multicolumn{9}{|c|}{ Panel A: Dependent Variables } \\
\hline CDI1 & 8334 & 0.022 & 0 & 5206 & 0.044 & 0 & $-0.022 * * *$ & $127.319^{* * *}$ \\
\hline CDI2 & 8334 & 0.041 & 0 & 5206 & 0.083 & 0 & $-0.042 * * *$ & $127.319^{* * *}$ \\
\hline \multicolumn{9}{|c|}{ Panel B: Independent Variables and Control Variables } \\
\hline GP & 8334 & 0.380 & 0 & 5206 & 0.432 & 0 & $-0.052 * * *$ & $0^{* * *}$ \\
\hline POLU & 8334 & 0.024 & 0.021 & 5206 & 0.033 & 0.031 & $-0.009 * * *$ & $-0.010^{* * *}$ \\
\hline BOARD & 8334 & 8.731 & 9 & 5206 & 9.094 & 9 & $-0.362 * * *$ & $0 * * *$ \\
\hline INDEP & 8334 & 0.372 & 0.333 & 5206 & 0.367 & 0.333 & $0.006^{* * *}$ & $0^{* * *}$ \\
\hline DUAL & 8334 & 0.238 & 0 & 5206 & 0.209 & 0 & $0.029 * * *$ & $0^{* * *}$ \\
\hline SIZE & 8334 & 21.700 & 21.580 & 5206 & 21.850 & 21.680 & $-0.151^{* * *}$ & $-0.100 * * *$ \\
\hline FIXA & 8334 & 0.186 & 0.152 & 5206 & 0.319 & 0.297 & $-0.133^{* * *}$ & $-0.145^{* * *}$ \\
\hline ROA & 8334 & 0.038 & 0.036 & 5206 & 0.037 & 0.034 & 0.001 & $0.002 * *$ \\
\hline CASH & 8334 & -0.178 & -0.132 & 5206 & -0.107 & -0.078 & $-0.071^{* * *}$ & $-0.054 * * *$ \\
\hline $\mathrm{M} / \mathrm{B}$ & 8334 & 2.277 & 1.651 & 5206 & 2.111 & 1.572 & $0.166^{* * *}$ & $0.079 * * *$ \\
\hline LEV & 8334 & 0.457 & 0.452 & 5206 & 0.461 & 0.455 & -0.004 & -0.003 \\
\hline AGE & 8334 & 9.428 & 9 & 5206 & 9.722 & 10 & -0.293 *** & $-1^{* * * *}$ \\
\hline BIG4 & 8334 & 0.026 & 0 & 5206 & 0.031 & 0 & $-0.005 *$ & 0 * \\
\hline FIRST & 8334 & 0.357 & 0.337 & 5206 & 0.367 & 0.353 & $-0.009^{* * *}$ & $-0.016^{* * *}$ \\
\hline
\end{tabular}

Note: Significance levels of $10 \%, 5 \%$, and $1 \%$ are denoted by ${ }^{*}, * *$, and ${ }^{* * *}$, respectively. 


\subsection{Panel Regression Analysis}

Table 6 shows the panel regression results. The first column shows that GP and POLU were significantly positively correlated with CDI1 at the 0.01 level after controlling for some variables, supporting hypotheses $\mathrm{H} 1$ and $\mathrm{H} 2$. The second column shows that, after controlling for all relevant variables, BOARD and INDEP were significantly positive with CDI1 at the 0.01 level, supporting hypotheses H3 and H4. DUAL was significantly negative with CDI1 at the 0.01 level, supporting H5. The third column takes all the independent variables into consideration, and the results show that GP, POLU, BOARD, and INDEP were significantly positively correlated with CDI1 at the 0.01 level, while DUAL was significantly negatively correlated with CDI1 at the 0.01 level, supporting hypotheses H1, $\mathrm{H} 2, \mathrm{H} 3, \mathrm{H} 4$, and $\mathrm{H} 5$. In the control variables, except for ROA, all other variables were significantly correlated with CDI1. SIZE, FIXA, CASH, M/B, AGE, BIG4, and FIRST were positively correlated with CDI1 at the 0.01 level or better, while LEV was significantly negatively correlated with CDI1 at the 0.1 level.

Table 6. Results of panel regression.

\begin{tabular}{cccc}
\hline & (1) CDI1 & (2) CDI1 & (3) CDI1 \\
\hline GP & $0.012^{* * *}(7.197)$ & & $0.010^{* * *}(6.139)$ \\
POLU & $0.011^{* * *}(5.445)$ & & $0.011^{* * *}(5.426)$ \\
BOARD & & $0.003^{* * *}(6.485)$ & $0.003^{* * *}(5.564)$ \\
INDEP & & $0.069^{* * *}(4.712)$ & $0.070^{* * *}(4.815)$ \\
DUAL & & $-0.005^{* * *}(-2.982)$ & $-0.004^{* *}(-2.200)$ \\
SIZE & $0.028^{* * *}(34.889)$ & $0.027^{* * *}(33.054)$ & $0.027^{* * *}(32.162)$ \\
FIXA & $0.024^{* * *}(4.804)$ & $0.028^{* * *}(5.798)$ & $0.022^{* * *}(4.443)$ \\
ROA & $-0.009^{*}(-0.642)$ & $-0.011^{*}(-0.817)$ & $-0.008(-0.567)$ \\
CASH & $0.008^{* * *}(4.052)$ & $0.008^{* * *}(4.177)$ & $0.008^{* * *}(3.874)$ \\
M/B & $0.004^{* * *}(8.748)$ & $0.004^{* * *}(8.240)$ & $0.004^{* * *}(8.384)$ \\
LEV & $-0.008^{* *}(-2.095)$ & $-0.007^{*}(-1.924)$ & $-0.008^{* *}(-2.241)$ \\
AGE & $0.000^{* * *}(3.504)$ & $0.001^{* * *}(5.874)$ & $0.000^{* * *}(3.484)$ \\
BIG4 & $0.055^{* * *}(12.430)$ & $0.054^{* * *}(12.131)$ & $0.054^{* * *}(12.211)$ \\
FIRST & $0.018^{* * *}(3.752)$ & $0.026^{* * *}(5.535)$ & $0.020^{* * *}(4.067)$ \\
constant & $-0.623^{* * *}(-34.864)$ & $-0.676^{* * *}(-36.988)$ & $-0.642^{* * *}(-34.850)$ \\
YEAR & controlled & controlled & controlled \\
IND & controlled & controlled & controlled \\
$N$ & 13,540 & 13,540 & 13,540 \\
Adjusted $R^{2}$ & 0.216 & 0.210 & 0.218
\end{tabular}

Note: The first column shows the results of independent variables GP and POLU. The second column shows the results of independent variables BOARD, INDEP, and DUAL. The third columns includes all variables. Year fixed effects and industry fixed effects are included in all regressions. $T$-values are reported in parentheses below coefficient estimates. Significance levels of $0.1,0.05$, and 0.01 are denoted by ${ }^{*} * *$, and ${ }^{* * *}$, respectively.

\subsection{Interaction between External Pressure and Internal Governance on Carbon Information Disclosure}

The results of the interaction between external pressure and internal governance on the carbon information disclosure are shown in Table 7. The first column shows the regression results of the effect of the interaction between GP and POLU on the carbon information disclosure, showing that, in state-owned enterprises and heavy polluting industries, the company's carbon information disclosure is even higher. The second column shows the regression results of the effect of the interaction between POLU and DUAL on the carbon information disclosure, showing that, when the level of corporate governance is higher, the positive impact of POLU on carbon information disclosure is more significant, supporting hypothesis H6. The third column shows the regression results of the effect of the interaction between GP and DUAL on the carbon information disclosure, showing that, when the level of corporate governance is higher, the positive impact of GP on carbon information disclosure is more significant, supporting hypothesis H6. The fourth column brings all interactions into the model, showing that the interaction between GP and POLU was significantly positively correlated with CDI1 at the 0.01 level, 
that between POLU and DUAL was significantly negatively correlated with CDI1 at the 0.01 level, and that between GP and DUAL was significantly negatively correlated with CDI1 at the 0.1 level, consistent with the results from the first three columns. The interaction between GP, POLU, and DUAL was significantly negatively correlated with CDI1 at the 0.1 level, showing that, when the level of corporate governance is higher, the positive impact of the interaction between GP and POLU on carbon information disclosure is more significant. All the above results support hypothesis $\mathrm{H6}$, whereby there is a complementary effect between external pressure and internal governance.

Table 7. The interaction between external pressure and internal governance.

\begin{tabular}{|c|c|c|c|c|}
\hline & (1) CDI1 & (2) CDI1 & (3) CDI1 & (4) CDI1 \\
\hline GP & $0.007^{* * *}(3.879)$ & $0.010^{* * *}(6.117)$ & $0.010^{* * *}(5.973)$ & $0.008^{* * *}(4.352)$ \\
\hline POLU & $0.007^{* * *}(3.087)$ & $0.014^{* * *}(6.313)$ & $0.012 * * *(5.601)$ & $0.010 * * *(3.959)$ \\
\hline $\mathrm{GP} \times \mathrm{POLU}$ & $0.012 * * *(4.428)$ & & & $0.009^{* * *}(3.040)$ \\
\hline POLU $\times$ DUAL & & $-0.010^{* * *}(-3.002)$ & & $-0.011^{* * *}(-2.737)$ \\
\hline $\mathrm{GP} \times \mathrm{DUAL}$ & & & $-0.001 * *(-2.349)$ & $-0.009 *(-1.658)$ \\
\hline $\begin{array}{c}\mathrm{GP} \times \mathrm{POLU} \times \\
\text { DUAL }\end{array}$ & & & & 7) \\
\hline BOARD & $0.003^{* * *}(5.782)$ & $0.003^{* * *}(5.860)$ & $0.003^{* * *}(5.822)$ & $0.003^{* * *}(5.790)$ \\
\hline INDEP & $0.064^{* * *}(4.368)$ & $0.065^{* * *}(4.447)$ & $0.065^{* * *}(4.439)$ & $0.064^{* * *}(4.372)$ \\
\hline DUAL & $-0.004^{* *}(-2.250)$ & $0.000(0.037)$ & $-0.003 *(-1.757)$ & $0.001(0.233)$ \\
\hline SIZE & $0.026^{* * *}(31.340)$ & $0.026^{* * *}(31.427)$ & $0.026^{* * *}(31.487)$ & $0.026^{* * *}(31.324)$ \\
\hline FIXA & $0.018^{* * *}(3.657)$ & $0.020 * * *(3.977)$ & $0.021^{* * *}(4.165)$ & $0.018^{* * *}(3.520)$ \\
\hline $\mathrm{ROA}$ & $-0.005(-0.371)$ & $-0.009(-0.633)$ & $-0.008(-0.595)$ & $-0.006(-0.469)$ \\
\hline $\mathrm{CASH}$ & $0.008^{* * *}(3.823)$ & $0.007^{* * *}(3.810)$ & $0.008^{* * *}(3.821)$ & $0.007^{* * *}(3.812)$ \\
\hline $\mathrm{M} / \mathrm{B}$ & $0.004^{* * *}(8.361)$ & $0.004^{* * *}(8.347)$ & $0.004^{* * *}(8.368)$ & $0.004^{* * *}(8.279)$ \\
\hline LEV & $-0.009^{* *}(-2.316)$ & $-0.008^{* *}(-2.241)$ & $-0.008^{* *}(-2.230)$ & $-0.009 * *(-2.272)$ \\
\hline AGE & $0.000 * * *(3.180)$ & $0.001^{* * *}(3.828)$ & $0.001^{* * *}(3.767)$ & $0.000 * * *(3.375)$ \\
\hline BIG4 & $0.053 * * *(11.914)$ & $0.053^{* * *}(11.899)$ & $0.053^{* * *}(11.887)$ & $0.053^{* * *}(11.866)$ \\
\hline FIRST & $0.019 * * *(3.917)$ & $0.019^{* * *}(3.941)$ & $0.020^{* * *}(4.018)$ & $0.019^{* * *}(3.832)$ \\
\hline Constant & $-0.644^{* * *}(-34.617)$ & $-0.649 * * *(-35.007)$ & $-0.650 * * *(-35.026)$ & $-0.645^{* * *}(-34.666)$ \\
\hline YEAR & controlled & controlled & controlled & controlled \\
\hline$I N D$ & controlled & controlled & controlled & controlled \\
\hline$N$ & 13,462 & 13,462 & 13,462 & 13,462 \\
\hline Adjusted $R^{2}$ & 0.213 & 0.212 & 0.212 & 0.213 \\
\hline
\end{tabular}

Note: The first column includes the results of the interactive effect of GP and POLU. The second column includes the results of the interactive effect of POLU and DUAL. The third column includes the results of the interactive effect of GP and DUAL. The fourth column includes the results of all interactive effects. Year fixed effects and industry fixed effects are included in all regressions. $T$-values are reported in parentheses below coefficient estimates. Significance levels of $0.1,0.05$, and 0.01 are denoted by $* * *$, and ${ }^{* * *}$, respectively.

\section{Robustness Tests}

\subsection{Endogeneity}

Although both the independent variables and the control variables in this model adopted the value of one lagging period for regression, the endogenous problem was overcome to a certain extent. In order to overcome the effect of this problem on the results of this paper, the Heckman two-stage self-selection model was used to retest the results.

In the first stage, the probity model was used to estimate the influencing factor of whether the listed companies seriously pollute the industry, and the inverse Mills ratio (lambda) was calculated (see model (4)); the control variables were consistent with model (1).

$$
\begin{gathered}
P O L U_{t+1}=\alpha+\beta_{1} * S_{Z} E_{t}+\beta_{2} * F I X A_{t}+\beta_{3} * \text { ROA }_{t}+\beta_{4} * C A S H_{t}+\beta_{5} * M / B_{t} \\
+\beta_{6} * L E V_{t}+\beta_{7} * A G E_{t}+\beta_{8} * B I G 4_{t}+\beta_{9} * F_{R S T}+Y E A R+I N D+\varepsilon
\end{gathered}
$$

The inverse Mills ratio (lambda) is obtained from the first-stage regression model and put into the second-stage regression model for self-selection correction. Table 8 shows the results of the second-stage regression model. The results show that GP, POLU, BOARD, and INDEP were significantly positively 
correlated with CDI1 at the 0.01 level, while DUAL was significantly negatively correlated with CDI1 at the 0.01 level, supporting hypotheses $\mathrm{H} 1, \mathrm{H} 2, \mathrm{H} 3, \mathrm{H} 4$, and $\mathrm{H} 5$.

Table 8. Results of the Heckman two-stage self-selection model.

\begin{tabular}{|c|c|c|c|}
\hline & (1) CDI1 & (2) CDI1 & (3) CDI1 \\
\hline GP & $0.032 * * *(6.387)$ & & $0.030^{* * *}(5.985)$ \\
\hline POLU & $0.011^{* * *}(5.476)$ & & $0.011^{* * *}(5.409)$ \\
\hline BOARD & & $0.003^{* * *}(6.181)$ & $0.003^{* * *}(5.743)$ \\
\hline INDEP & & $0.062^{* * *}(4.215)$ & $0.064^{* * *}(4.374)$ \\
\hline DUAL & & $-0.004^{* *}(-2.366)$ & $-0.004^{* *}(-2.103)$ \\
\hline SIZE & $0.027^{* * *}(32.920)$ & $0.027^{* * *}(32.398)$ & $0.026^{* * *}(30.453)$ \\
\hline FIXA & $0.010 *(1.779)$ & $0.032^{* * *}(6.378)$ & $0.009(1.507)$ \\
\hline ROA & $-0.007(-0.501)$ & $-0.011(-0.804)$ & $-0.006(-0.444)$ \\
\hline CASH & $0.007 * * *(3.692)$ & $0.008^{* * *}(4.077)$ & $0.007^{* * *}(3.518)$ \\
\hline $\mathrm{M} / \mathrm{B}$ & $0.004^{* * *}(8.406)$ & $0.004^{* * *}(8.308)$ & $0.004^{* * *}(8.088)$ \\
\hline LEV & $-0.008^{* *}(-2.158)$ & $-0.008^{* *}(-2.202)$ & $-0.009^{* *}(-2.347)$ \\
\hline AGE & $0.000^{* * *}(3.263)$ & $0.001^{* * *}(4.880)$ & $0.000^{* * *}(3.247)$ \\
\hline BIG4 & $0.054^{* * *}(12.265)$ & $0.053^{* * *}(11.820)$ & $0.054^{* * *}(12.064)$ \\
\hline FIRST & $0.016^{* * *}(3.277)$ & $0.024 * * *(4.894)$ & $0.018^{* * *}(3.640)$ \\
\hline lambda & $-0.010^{* * *}(-4.284)$ & $0.003^{* * *}(4.041)$ & $-0.010^{* * *}(-4.191)$ \\
\hline Constant & $-0.583^{* * *}(-29.430)$ & $-0.674^{* * *}(-36.559)$ & $-0.602^{* * *}(-29.558)$ \\
\hline$Y E A R$ & controlled & controlled & controlled \\
\hline$I N D$ & controlled & controlled & controlled \\
\hline$N$ & 13,390 & 13,390 & 13,390 \\
\hline Adjusted $R^{2}$ & 0.216 & 0.209 & 0.218 \\
\hline
\end{tabular}

Note: The first column includes the results of GP and POLU. The second column includes the results of the interactive effect of BOARD, INDEP, and DUAL. The third column includes the results of all variables. Year fixed effects and industry fixed effects are included in all regressions. $T$-values are reported in parentheses below coefficient estimates. Significance levels of $0.1,0.05$, and 0.01 are denoted by ${ }^{*}{ }^{* *}$, and ${ }^{* * *}$, respectively.

\subsection{Propensity Score Matching (PSM)}

From Table 1, we can see that the sample of listed companies in the heavy polluting industries accounts for $38.4 \%$, which led to sample deviation, thus affecting the results of this study. In order to eliminate the above effect, the PSM matching method was used to retest the model. Firstly, we took the first-stage regression model for the dummy variables of heavy pollution by controlling for other variables, and the scores of each observation were obtained. Secondly, according to the scores of the regression, the heavy polluting industries and non-heavy polluting industries were selected. Samples from heavy polluting industries were matched according to their nearest neighbor 1:1. Table 9 shows the results of matching regression. The results show that GP, POLU, BOARD, and INDEP were significantly positively correlated with CDI1 at the 0.01 level, while DUAL was significantly negatively correlated with CDI1 at the 0.01 level, supporting hypotheses H1, H2, H3, H4, and H5.

Table 9. Results of propensity score matching.

\begin{tabular}{cccc}
\hline & (1) CDI1 & (2) CDI1 & (3) CDI1 \\
\hline GP & $0.015^{* * *}(5.501)$ & & $0.013^{* * *}(4.710)$ \\
POLU & $0.011^{* * *}(3.496)$ & & $0.011^{* * *}(3.488)$ \\
BOARD & & $0.003^{* * *}(4.172)$ & $0.003^{* * *}(3.423)$ \\
INDEP & & $0.064^{* * *}(2.615)$ & $0.063^{* * *}(2.591)$ \\
DUAL & & $-0.009^{* * *}(-3.071)$ & $-0.007^{* * *}(-2.577)$ \\
SIZE & $0.032^{* * *}(23.124)$ & $0.031^{* * *}(22.244)$ & $0.030^{* * *}(21.455)$ \\
FIXA & $0.019^{* *}(2.449)$ & $0.025^{* * *}(3.153)$ & $0.018^{* *}(2.270)$ \\
ROA & $-0.014^{*}(-0.633)$ & $-0.013^{* * 0.612)}$ & $-0.015(-0.686)$ \\
CASH & $0.008^{* *}(2.234)$ & $0.007^{* *}(2.148)$ & $0.007^{* *}(2.088)$ \\
\hline
\end{tabular}


Table 9. Cont.

\begin{tabular}{cccc}
\hline & (1) CDI1 & (2) CDI1 & (3) CDI1 \\
\hline M/B & $0.004^{* * *}(5.515)$ & $0.004^{* * *}(5.303)$ & $0.004^{* * *}(5.352)$ \\
LEV & $-0.011^{*}(-1.717)$ & $-0.011^{*}(-1.788)$ & $-0.012^{*}(-1.935)$ \\
AGE & $0.000(1.594)$ & $0.001^{* * *}(3.209)$ & $0.000(1.575)$ \\
BIG4 & $0.055^{* * *}(7.539)$ & $0.055^{* * *}(7.512)$ & $0.055^{* * *}(7.485)$ \\
FIRST & $0.019^{* *}(2.292)$ & $0.029^{* * *}(3.604)$ & $0.021^{* *}(2.477)$ \\
Constant & $-0.750^{* * *}(-23.469)$ & $-0.721^{* * *}(-23.307)$ & $-0.764^{* * *}(-23.206)$ \\
YEAR & controlled & controlled & controlled \\
IND & controlled & controlled & controlled \\
$N$ & 6414 & 6414 & 6414 \\
Adjusted $R^{2}$ & 0.217 & 0.212 & 0.220
\end{tabular}

Note: The first column includes the results of GP and POLU. The second column includes the results of the interactive effect of BOARD, INDEP, and DUAL The third column includes the results of all variables. Year fixed effects and industry fixed effects are included in all regressions. $T$-values are reported in parentheses below coefficient estimates. Significance levels of $0.1,0.05$, and 0.01 are denoted by ${ }^{*}, *$, and ${ }^{* * *}$, respectively.

\subsection{Sensitivity of the Dependent Variable}

In order to ensure the robustness of the results, we used CDI2 instead of CDI1 to retest the model (see Table 10) the results show that GP, POLU, BOARD, and INDEP were significantly positively correlated with CDI1 at the 0.01 level, while DUAL was significantly negatively correlated with CDI1 at the 0.01 level, supporting hypotheses $\mathrm{H} 1, \mathrm{H} 2, \mathrm{H} 3, \mathrm{H} 4$, and H5. Thus, the above conclusions are still robust.

Table 10. Results using CDI2 instead of CDI1.

\begin{tabular}{|c|c|c|c|}
\hline & (1) CDI2 & (2) CDI2 & (3) CDI2 \\
\hline GP & $0.023^{* * *}(7.094)$ & & $0.020^{* * *}(6.087)$ \\
\hline POLU & $0.022^{* * *}(5.661)$ & & $0.022^{* * *}(5.600)$ \\
\hline BOARD & & $0.006^{* * *}(6.681)$ & $0.005^{* * *}(5.841)$ \\
\hline INDEP & & $0.128^{* * *}(4.519)$ & $0.131^{* * *}(4.666)$ \\
\hline DUAL & & $-0.009 * * *(-2.865)$ & $-0.007^{* *}(-2.097)$ \\
\hline SIZE & $0.053^{* * *}(33.766)$ & $0.052 * * *(32.389)$ & $0.050^{* * *(31.160)}$ \\
\hline FIXA & $0.045^{* * *}(4.731)$ & $0.056^{* * *}(5.884)$ & $0.042 * * *(4.355)$ \\
\hline ROA & $-0.024(-0.918)$ & $-0.026(-0.977)$ & $-0.022(-0.846)$ \\
\hline CASH & $0.015^{* * *}(3.950)$ & $0.015^{* * *}(4.053)$ & $0.014^{* * *}(3.771)$ \\
\hline $\mathrm{M} / \mathrm{B}$ & $0.008^{* * *}(8.559)$ & $0.007^{* * *}(8.137)$ & $0.007^{* * *}(8.218)$ \\
\hline LEV & $-0.015^{* *}(-2.067)$ & $-0.015^{* *}(-2.027)$ & $-0.016^{* *}(-2.251)$ \\
\hline AGE & $0.001^{* * *}(3.560)$ & $0.002^{* * *}(5.988)$ & $0.001^{* * *}(3.540)$ \\
\hline BIG4 & $0.106^{* * *}(12.365)$ & $0.104^{* * *}(12.142)$ & $0.104^{* * *}(12.155)$ \\
\hline FIRST & $0.038^{* * *}(4.037)$ & $0.054^{* * *}(5.893)$ & $0.041^{* * *}(4.384)$ \\
\hline Constant & $-1.179 * * *(-33.957)$ & $-1.287^{* * *}(-36.309)$ & $-1.216^{* * *}(-33.962)$ \\
\hline$Y E A R$ & controlled & controlled & controlled \\
\hline$I N D$ & controlled & controlled & controlled \\
\hline$N$ & 13,462 & 13,462 & 13,462 \\
\hline Adjusted $R^{2}$ & 0.213 & 0.207 & 0.215 \\
\hline
\end{tabular}

Note: The first column includes the results of GP and POLU. The second column includes the results of the interactive effect of BOARD, INDEP, and DUAL. The third column includes the results of all variables. Year fixed effects and industry fixed effects are included in all regressions. $T$-values are reported in parentheses below coefficient estimates. Significance levels of $0.1,0.05$, and 0.01 are denoted by $* * *$, and ${ }^{* * *}$, respectively.

\subsection{Sub-Sample Test}

The first three columns of Table 11 show the regression results of the model excluding growth enterprise market (GEM)-listed companies. Previous studies argued that there are great differences between GEM-listed companies and Shanghai and Shenzhen mainboard-listed companies in terms of company size, growth, and information disclosure [21,22]. To reduce the effect of sample deviation 
on the results of this paper, this paper eliminated GEM companies and retested the model. The first column shows that GP and POLU were significantly positively correlated with CDI1 at the 0.01 level. The second column shows that BOARD and INDEP were significantly positively correlated with CDI1 at the 0.01 level, while DUAL was significantly negatively correlated with CDI1 at the 0.01 level. The results of the third column are consistent with the result of the first and second columns. The above results support hypotheses $\mathrm{H} 1, \mathrm{H} 2, \mathrm{H} 3, \mathrm{H} 4$, and $\mathrm{H} 5$.

Table 11. Results of sub-sample excluding growth enterprise market (GEM)-listed companies and including only those in the manufacturing industry.

\begin{tabular}{|c|c|c|c|c|c|c|}
\hline & \multicolumn{3}{|c|}{ Excluding GEM } & \multicolumn{3}{|c|}{ Manufacturing Industry } \\
\hline & (1) & (2) & (3) & (4) & (5) & (6) \\
\hline & CDI1 & CDI1 & CDI1 & CDI1 & CDI1 & CDI1 \\
\hline GP & $\begin{array}{c}0.012 * * * \\
(6.562)\end{array}$ & & $\begin{array}{c}0.010^{* * *} \\
(5.551)\end{array}$ & $\begin{array}{c}0.015^{* * *} \\
(6.788)\end{array}$ & & $\begin{array}{c}0.013^{* * *} \\
(5.670)\end{array}$ \\
\hline POLU & $\begin{array}{c}0.012 * * * \\
(5.311)\end{array}$ & & $\begin{array}{c}0.012 * * * \\
(5.239)\end{array}$ & $\begin{array}{c}0.010^{* * *} \\
(3.883) \\
\end{array}$ & & $\begin{array}{c}0.009 * * * \\
(3.690)\end{array}$ \\
\hline BOARD & & $\begin{array}{c}0.003^{* * *} \\
(6.521)\end{array}$ & $\begin{array}{c}0.003 * * * \\
(5.786)\end{array}$ & & $\begin{array}{c}0.005^{* * *} \\
(7.338)\end{array}$ & $\begin{array}{c}0.004 * * * \\
(6.395)\end{array}$ \\
\hline INDEP & & $\begin{array}{c}0.067^{* * *} \\
(4.137)\end{array}$ & $\begin{array}{c}0.068^{* * *} \\
(4.247)\end{array}$ & & $\begin{array}{c}0.070^{* * *} \\
(3.591)\end{array}$ & $\begin{array}{c}0.070 * * * \\
(3.600)\end{array}$ \\
\hline DUAL & & $\begin{array}{c}-0.006^{* * *} \\
(-2.888)\end{array}$ & $\begin{array}{l}-0.004 \text { ** } \\
(-2.183)\end{array}$ & & $\begin{array}{l}-0.005^{* *} \\
(-2.190)\end{array}$ & $\begin{array}{l}-0.003 * \\
(-1.911)\end{array}$ \\
\hline SIZE & $\begin{array}{l}0.028^{* * *} \\
(32.161)\end{array}$ & $\begin{array}{l}0.028^{* * *} \\
(30.566)\end{array}$ & $\begin{array}{l}0.027^{* * *} \\
(29.561)\end{array}$ & $\begin{array}{l}0.032 * * * \\
(28.746)\end{array}$ & $\begin{array}{l}0.031 * * * \\
(27.572)\end{array}$ & $\begin{array}{l}0.030 * * * \\
(26.357)\end{array}$ \\
\hline FIXA & $\begin{array}{c}0.025^{* * *} \\
(4.565)\end{array}$ & $\begin{array}{c}0.030^{* * *} \\
(5.634)\end{array}$ & $\begin{array}{c}0.023 * * * \\
(4.206)\end{array}$ & $\begin{array}{c}0.018^{* * *} \\
(2.681)\end{array}$ & $\begin{array}{c}0.025^{* * *} \\
(3.852)\end{array}$ & $\begin{array}{l}0.017^{* *} \\
(2.494)\end{array}$ \\
\hline ROA & $\begin{array}{c}-0.012 \\
(-0.847)\end{array}$ & $\begin{array}{c}-0.013 \\
(-0.885)\end{array}$ & $\begin{array}{c}-0.011 \\
(-0.779)\end{array}$ & $\begin{array}{c}-0.004 \\
(-0.232)\end{array}$ & $\begin{array}{c}-0.006 \\
(-0.326)\end{array}$ & $\begin{array}{c}-0.005 \\
(-0.288)\end{array}$ \\
\hline $\mathrm{CASH}$ & $\begin{array}{c}0.009^{* * *} \\
(4.002)\end{array}$ & $\begin{array}{c}0.009^{* * *} \\
(4.105)\end{array}$ & $\begin{array}{c}0.008^{* * *} \\
(3.843)\end{array}$ & $\begin{array}{c}0.009^{* * *} \\
(3.154)\end{array}$ & $\begin{array}{c}0.009^{* * *} \\
(3.143)\end{array}$ & $\begin{array}{c}0.008^{* * *} \\
(3.008)\end{array}$ \\
\hline $\mathrm{M} / \mathrm{B}$ & $\begin{array}{c}0.004^{* * *} \\
(8.457)\end{array}$ & $\begin{array}{c}0.004^{* * *} \\
(7.952)\end{array}$ & $\begin{array}{c}0.004 * * * \\
(8.086)\end{array}$ & $\begin{array}{c}0.004^{* * *} \\
(6.460)\end{array}$ & $\begin{array}{c}0.004 * * * \\
(6.059)\end{array}$ & $\begin{array}{c}0.004 * * * \\
(6.145)\end{array}$ \\
\hline LEV & $\begin{array}{l}-0.007 * \\
(-1.792)\end{array}$ & $\begin{array}{l}-0.008 * \\
(-1.814)\end{array}$ & $\begin{array}{l}-0.008^{* *} \\
(-1.999)\end{array}$ & $\begin{array}{l}-0.011 \text { ** } \\
(-2.200)\end{array}$ & $\begin{array}{l}-0.012 \text { ** } \\
(-2.423)\end{array}$ & $\begin{array}{c}-0.013 \text { ** } \\
(-2.572)\end{array}$ \\
\hline AGE & $\begin{array}{c}0.001 * * * \\
(3.616)\end{array}$ & $\begin{array}{c}0.001^{* * *} \\
(5.616)\end{array}$ & $\begin{array}{c}0.001 \text { *** } \\
(3.604)\end{array}$ & $\begin{array}{c}0.001^{* * *} \\
(3.333)\end{array}$ & $\begin{array}{c}0.001 \text { *** } \\
(5.979)\end{array}$ & $\begin{array}{c}0.001 * * * \\
(3.591)\end{array}$ \\
\hline BIG4 & $\begin{array}{l}0.055^{* * *} \\
(11.560)\end{array}$ & $\begin{array}{l}0.054^{* * *} \\
(11.365)\end{array}$ & $\begin{array}{l}0.054^{* * *} \\
(11.380)\end{array}$ & $\begin{array}{c}0.044^{* * *} \\
(7.563)\end{array}$ & $\begin{array}{c}0.043^{* * *} \\
(7.424)\end{array}$ & $\begin{array}{c}0.043^{* * *} \\
(7.410)\end{array}$ \\
\hline FIRST & $\begin{array}{c}0.020^{* * * *} \\
(3.790)\end{array}$ & $\begin{array}{c}0.029^{* * *} \\
(5.489)\end{array}$ & $\begin{array}{c}0.022 * * * \\
(4.109)\end{array}$ & $\begin{array}{c}0.020^{* * *} \\
(3.065)\end{array}$ & $\begin{array}{c}0.032 * * * \\
(4.868)\end{array}$ & $\begin{array}{c}0.023 \text { *** } \\
(3.519)\end{array}$ \\
\hline Constant & $\begin{array}{l}-0.639 * * * \\
(-32.258)\end{array}$ & $\begin{array}{l}-0.692 * * * \\
(-34.310)\end{array}$ & $\begin{array}{l}-0.656^{* * *} \\
(-32.280)\end{array}$ & $\begin{array}{l}-0.748 \text { *** } \\
(-27.977)\end{array}$ & $\begin{array}{l}-0.733 * * * \\
(-29.241)\end{array}$ & $\begin{array}{l}-0.769 \text { *** } \\
(-27.929)\end{array}$ \\
\hline YEAR & controlled & controlled & controlled & & & \\
\hline$I N D$ & controlled & controlled & controlled & & & \\
\hline$N$ & 11,980 & 11,980 & 11,980 & 9123 & 9123 & 9123 \\
\hline Adjusted $R^{2}$ & 0.213 & 0.207 & 0.216 & 0.213 & 0.211 & 0.217 \\
\hline
\end{tabular}

Note: The first three columns include the results of the subsample excluding GEM-listed companies. The fourth to sixth columns include the results of the subsample including companies only from the manufacturing industry. Year fixed effects and industry fixed effects are included in all regressions. $T$-values are reported in parentheses below coefficient estimates. Significance levels of $0.1,0.05$, and 0.01 are denoted by ${ }^{*}{ }^{* *}$, and ${ }^{* * *}$, respectively.

At the same time, some scholars believed that that there are some differences in carbon information disclosure between listed companies in the manufacturing industry and that of listed companies in other industries [23]. Therefore, we retested the model using only listed companies in the manufacturing 
industry [24]. The fourth to sixth columns show that that GP and POLU were significantly positively correlated with CDI1 at the 0.01 level. Furthermore, BOARD and INDEP were significantly positively correlated with CDI1 at the 0.01 level of significance, while DUAL was significantly negatively correlated with CDI1 at the 0.01 level, also supporting hypotheses H1, H2, H3, H4, and H5.

\subsection{Two-Way Clustering (Company and Year)}

This model may face a problem of self-correlation between the perturbations, mainly because of the existence of individual effects (sequence correlation) and time effects (cross-section correlation) in the panel data [16]. This paper used two-way clustering (company clustering and year clustering) to retest the model. The first three columns of Table 12 show that GP and POLU were significantly positively correlated with CDI1 at the 0.01 level. Furthermore, BOARD and INDEP were significantly positively correlated with CDI1 at the 0.01 level, while DUAL was significantly negatively correlated with CDI1 at the 0.01 level, also supporting hypotheses H1, H2, H3, H4, and H5.

Table 12. Results of two-way clustering (company and year).

\begin{tabular}{cccc}
\hline & \multicolumn{3}{c}{ Two-Way Clustering (Company and Year) } \\
\cline { 2 - 4 } & $\mathbf{( 1 )}$ & $\mathbf{( 2 )}$ & $\mathbf{( 3 )}$ \\
\hline CDI1 & CDI1 & CDI1 \\
\hline GP & $0.010^{* *}(2.413)$ & & $0.008^{* *}(2.068)$ \\
POLU & $0.009^{* * *}(3.007)$ & & $0.009^{* * *}(2.958)$ \\
BOARD & & $0.003^{* * *}(3.626)$ & $0.003^{* * *}(3.254)$ \\
INDEP & & $0.075^{* * *}(3.094)$ & $0.072^{* * *}(3.005)$ \\
DUAL & & $-0.004^{* *}(-1.798)$ & $-0.003^{*}(-1.732)$ \\
SIZE & $0.025^{* * *}(9.127)$ & $0.025^{* * *}(7.614)$ & $0.024^{* * *}(8.814)$ \\
FIXA & $0.015^{*}(1.753)$ & $0.038^{* * *}(3.945)$ & $0.013(1.519)$ \\
ROA & $-0.008^{* *}(-0.474)$ & $0.001(0.063)$ & $-0.008(-0.463)$ \\
CASH & $0.008^{* * *}(2.819)$ & $0.009^{* * *}(2.852)$ & $0.008^{* * *}(2.712)$ \\
M/B & $0.003^{* * *}(3.004)$ & $0.002(1.428)$ & $0.003^{* * *}(3.041)$ \\
LEV & $-0.012^{* *}(-2.053)$ & $-0.015^{* *}(-2.545)$ & $-0.012^{* *}(-2.230)$ \\
AGE & $0.000(0.887)$ & $0.000(1.614)$ & $0.000(0.954)$ \\
BIG4 & $0.052^{* * *}(3.214)$ & $0.055^{* * *}(3.414)$ & $0.050^{* * *}(3.137)$ \\
FIRST & $0.014(1.565)$ & $0.026^{* * *}(2.727)$ & $0.016^{*}(1.775)$ \\
Constant & $-0.558^{* * *}(-9.499)$ & $-0.596^{* * *}(-8.356)$ & $-0.581^{* * *}(-9.818)$ \\
$N$ & 13,462 & $13^{*} 462$ & 13,462 \\
Adjusted $R^{2}$ & 0.198 & 0.180 & 0.201 \\
\hline
\end{tabular}

Note: The first column includes the results of GP and POLU. The second column includes the results of the interactive effect of BOARD, INDEP, and DUAL. The third column includes the results of all variables. Variable definitions are provided in Appendix A. Year fixed effects and industry fixed effects are included in all regressions. $T$-values are reported in parentheses below coefficient estimates. Significance levels of $0.1,0.05$, and 0.01 are denoted by ${ }^{* * *}$, and ${ }^{* * *}$, respectively.

\section{Conclusions and Implications}

\subsection{Conclusions}

This paper used manually collected data of carbon information disclosure for listed companies, from 2009 to 2015 in China, to explore the impact of external pressure and company governance on carbon information disclosure. The results show that, firstly, the greater the external pressure is, the higher the level of carbon information disclosure will be (this holds the same view as Braam [14]); that is, when listed companies are state-owned enterprises or in heavy polluting industries, the level of carbon information disclosure is higher, which is in line with stakeholder theory that companies must also assume social and political responsibilities, and that business decisions must be based on their interests or accept their constraints. Secondly, the higher the level of corporate governance is, the higher the level of carbon information disclosure will be; that is, when the board of directors 
is larger, the proportion of independent directors is higher, and the chairman and general manager positions are differentiated, the level of carbon information disclosure is higher (this holds the same view as Shaukat [6]). Further analysis showed that, firstly, when listed companies are state-owned and in heavy polluting industries, the level of carbon information disclosure is higher. Secondly, when the chairman and general manager are in the same position (lower governance level), the positive impact of GP on carbon disclosure is less significant, the positive impact of POLU on carbon disclosure is less significant, and the positive impact of the interaction between GP and POLU on carbon disclosure is less significant. The experimental results in this paper validate and supplement the theory of organizational legitimacy. Legitimacy theory is based on a "contract"; as a link between enterprise and society, a contract integrates the enterprise into society. The legitimacy of an enterprise is the prerequisite for its continuing operation, and violation of the "contract" will have a negative impact. Legitimacy theory is one of the possible motivations for management to disclose environmental information. Enterprises voluntarily disclose information in order to obtain public support and to prove that their behavior conforms to social values, thereby maintaining their legitimacy.

\subsection{Implications}

From the perspective of public pressure, this paper empirically examined the correlation between public pressure and carbon information disclosure level, and considered the impact of the ownership nature of enterprises on the relationship between them. Studying the relationship between public pressure, governance nature, and carbon information disclosure can promote enterprises to actively disclose carbon information, meet the information needs of stakeholders, and provide ideas and suggestions for relevant government regulatory departments to establish and improve the standards of carbon information disclosure. The research implications are discussed below.

Firstly, external pressure can improve the level of carbon disclosure, which is the key factor affecting the level of carbon disclosure. Therefore, in China, regulators and stakeholders can promote more listed companies to disclose carbon information by raising the level of external pressure.

Second, internal governance level can promote carbon information disclosure; therefore, regulatory authorities can improve the level of internal governance of listed companies by enacting relevant laws and regulations, thereby improving the level of carbon information disclosure of listed companies.

Thirdly, external pressure and internal governance level have complementary effects on the level of carbon information disclosure. Government departments, stakeholders, and listed companies can each have their own advantages, from the perspective of external pressure and internal governance, through joint efforts to improve the level of carbon disclosure of listed companies.

Author Contributions: P.H. and H.S. conceived and designed the research method used in this paper; Y.Z. collected the data used for empirical analysis; J.R. performed the empirical analysis and wrote the paper.

Acknowledgments: This work was supported by the National Social Science Fund of China (17BGL051), the Fundamental Research Funds for the Central Universities (2019FR005), the Fundamental Research Funds for the Central Universities (2018QN068), and the Beijing Social Science Fund (18GLB017).

Conflicts of Interest: The authors declare no conflicts of interest.

\section{Appendix A}

Step 1: Building the judgment matrix

The judgment matrix was constructed using a 1-9 scaling method. The relative importance of each evaluation index was described qualitatively and quantitatively with accurate figures. Number 1 in the judgment matrix indicates that two elements are equally important to a certain attribute, while number 9 indicates that the first element is more important than the second when comparing them. Intermediate numbers scale between both meanings. 
Table A1. CDI: T1-T6 judgment matrices.

\begin{tabular}{ccccccc}
\hline CDI & T1 & T2 & T3 & T4 & T5 & T6 \\
\hline T1 & 1 & $1 / 2$ & $1 / 4$ & $1 / 5$ & $1 / 7$ & 3 \\
T2 & 2 & 1 & $1 / 2$ & $1 / 3$ & $1 / 4$ & 4 \\
T3 & 4 & 2 & 1 & $1 / 2$ & $1 / 5$ & 5 \\
T4 & 5 & 3 & 2 & 1 & $1 / 2$ & 6 \\
T5 & 7 & 4 & 5 & 2 & 1 & 7 \\
T6 & $1 / 3$ & $1 / 4$ & $1 / 5$ & $1 / 6$ & $1 / 7$ & 1 \\
\hline
\end{tabular}

Table A2. T1: I1-I2 judgment matrices.

\begin{tabular}{ccc}
\hline T1 & I1 & I2 \\
\hline I1 & 1 & $1 / 2$ \\
I2 & 2 & 1 \\
\hline
\end{tabular}

Table A3. T2: I3-I6 judgment matrices.

\begin{tabular}{ccccc}
\hline T2 & I3 & I4 & I5 & I6 \\
\hline I3 & 1 & $1 / 3$ & $1 / 5$ & $1 / 4$ \\
I4 & & 1 & $1 / 3$ & $1 / 2$ \\
I5 & & & 1 & 2 \\
I6 & & & & 1 \\
\hline
\end{tabular}

Table A4. T3: I7-I8 judgment matrices.

\begin{tabular}{ccc}
\hline T1 & I7 & I8 \\
\hline I7 & 1 & 1 \\
I8 & 1 & 1 \\
\hline
\end{tabular}

Table A5. T4: I9-I11 judgment matrices.

\begin{tabular}{cccc}
\hline T4 & I9 & I10 & I11 \\
\hline I9 & 1 & 2 & 1 \\
I10 & & 1 & $1 / 2$ \\
I11 & & & 1 \\
\hline
\end{tabular}

Table A6. T5: I12-I14 judgment matrices.

\begin{tabular}{cccc}
\hline T4 & I2 & I13 & I14 \\
\hline I12 & 1 & 1 & 2 \\
I13 & $1 / 2$ & 1 & 2 \\
I14 & $1 / 2$ & $1 / 2$ & 1 \\
\hline
\end{tabular}

Step 2: Hierarchical single ranking results

Using the square-root method to solve the weight of each index, the N-power root of the product of each row element of the judgment matrix was calculated ( $n$ is the order of the judgment matrix), thereby normalizing the processing. The eigenvector of the judgment matrix was then obtained (i.e., the index weight). The maximum eigenvalue $\left(\lambda_{\max }\right)$ and consistency index $(\mathrm{CI})$ of the judgment matrix were both less than 0.1 . The results show that the hierarchical ranking of the judgment matrix meets the requirements of consistency test. The results are shown in Table A8. 
Table A7. Hierarchical single ranking results of each judgment matrix.

\begin{tabular}{|c|c|c|c|c|c|c|c|}
\hline \multirow{2}{*}{$\begin{array}{c}\text { Judgment } \\
\text { Matrix }\end{array}$} & \multicolumn{6}{|c|}{ Index Weight } & \multirow{2}{*}{ Consistency Check } \\
\hline & T1 & T2 & T3 & $\mathrm{T} 4$ & T5 & T6 & \\
\hline CDI: T1-T6 & 0.0553 & 0.0981 & 0.1484 & 0.2494 & 0.4168 & 0.0319 & $\mathrm{CI}=0.0413, \lambda_{\max }: 6.2603$ \\
\hline \multirow{2}{*}{$\begin{array}{l}\text { Judgment } \\
\text { matrix }\end{array}$} & \multicolumn{6}{|c|}{ Index weight } & \multirow{2}{*}{ Consistency check } \\
\hline & \multicolumn{3}{|c|}{ I1 } & \multicolumn{3}{|c|}{ I2 } & \\
\hline T1: I1-I2 & \multicolumn{3}{|c|}{0.3333} & \multicolumn{3}{|c|}{0.6667} & $\mathrm{CI}=0.0000, \lambda_{\max }: 2.000$ \\
\hline \multirow{2}{*}{$\begin{array}{l}\text { Judgment } \\
\text { matrix }\end{array}$} & \multicolumn{6}{|c|}{ Index weight } & \multirow{2}{*}{ Consistency check } \\
\hline & I3 & I4 & & I5 & I6 & & \\
\hline T2: I3-I6 & 0.0725 & 0.16 & & 0.4723 & 0.28 & & $\mathrm{CI}=0.0191, \lambda_{\max }: 4.0511$ \\
\hline \multirow{2}{*}{$\begin{array}{l}\text { Judgment } \\
\text { matrix }\end{array}$} & \multicolumn{6}{|c|}{ Index weight } & \multirow{2}{*}{ Consistency check } \\
\hline & & I7 & & & I8 & & \\
\hline T3: I7-I8 & & 0.5000 & & & 0.5000 & & $C I=0.0000, \lambda_{\max }: 2.000$ \\
\hline \multirow{2}{*}{$\begin{array}{l}\text { Judgment } \\
\text { matrix }\end{array}$} & \multicolumn{6}{|c|}{ Index weight } & \multirow{2}{*}{ Consistency check } \\
\hline & IS & & I1 & & I1 & & \\
\hline T4: I9-I11 & 0.4 & 00 & 0.20 & 00 & 0.40 & & $C I=0.0000, \lambda_{\max }: 3.000$ \\
\hline \multirow{2}{*}{$\begin{array}{l}\text { Judgment } \\
\text { matrix }\end{array}$} & \multicolumn{6}{|c|}{ Index weight } & \multirow{2}{*}{ Consistency check } \\
\hline & I1 & & I1 & & I1 & & \\
\hline T5: I12-I4 & 0.40 & 00 & 0.40 & 00 & 0.20 & & $\mathrm{CI}=0.0000, \lambda_{\max }: 3.000$ \\
\hline
\end{tabular}

Step 3: Total ranking results

Table A8. Total ranking results of evaluation indices.

\begin{tabular}{cccccccc}
\hline $\begin{array}{c}\text { Evaluating } \\
\text { Indicator }\end{array}$ & \multicolumn{7}{c}{ Index Weight } \\
\hline I1 & 0.3333 & 0 & 0 & 0 & 0 & 0 & $\begin{array}{c}\text { Index Layer } \\
\text { Combination Weight }\end{array}$ \\
I2 & 0.6667 & 0 & 0 & 0 & 0 & 0 & 0.0184 \\
I3 & 0 & 0.0725 & 0 & 0 & 0 & 0 & 0.0369 \\
I4 & 0 & 0.1697 & 0 & 0 & 0 & 0 & 0.0071 \\
I5 & 0 & 0.4723 & 0 & 0 & 0 & 0 & 0.0166 \\
I6 & 0 & 0.2854 & 0 & 0 & 0 & 0 & 0.0463 \\
I7 & 0 & 0 & 0.5000 & 0 & 0 & 0 & 0.0280 \\
I8 & 0 & 0 & 0.5000 & 0 & 0 & 0 & 0.0742 \\
I9 & 0 & 0 & 0 & 0.4000 & 0 & 0 & 0.0742 \\
I10 & 0 & 0 & 0 & 0.2000 & 0 & 0 & 0.0998 \\
I11 & 0 & 0 & 0 & 0.4000 & 0 & 0 & 0.0499 \\
I12 & 0 & 0 & 0 & 0 & 0.4000 & 0 & 0.0998 \\
I13 & 0 & 0 & 0 & 0 & 0.4000 & 0 & 0.1667 \\
I14 & 0 & 0 & 0 & 0 & 0.2000 & 0 & 0.1667 \\
I15 & 0 & 0 & 0 & 0 & 0 & 1.0000 & 0.0834 \\
\hline
\end{tabular}

\section{References}

1. Zeng, S.X.; Xu, X.D.; Dong, Z.Y.; Tam, V.W.Y. Towards corporate environmental information disclosure: An empirical study in China. J. Clean. Prod. 2010, 18, 1142-1148. [CrossRef]

2. Zeng, S.X.; Xu, X.D.; Yin, H.T.; Tam, C.M. Factors that drive Chinese listed companies in voluntary disclosure of environmental information. J. Bus. Ethics 2012, 109, 309-321. [CrossRef] 
3. Meng, X.H.; Zeng, S.X.; Tam, C.M. From voluntarism to regulation: A study on ownership, economic performance and corporate environmental information disclosure in china. J. Bus. Ethics 2013, 116, 217-232. [CrossRef]

4. Meng, X.H.; Zeng, S.X.; Tam, C.M.; Xu, X.D. Whether top executives' turnover influences environmental responsibility: From the perspective of environmental information disclosure. J. Bus. Ethics 2013, 114, 341-353. [CrossRef]

5. Yao, S.; Liang, H. Firm location, political geography and environmental information disclosure. Appl. Econ. 2017, 49, 251-262. [CrossRef]

6. Shaukat, A.; Qiu, Y.; Trojanowski, G. Board attributes, corporate social responsibility strategy, and corporate environmental and social performance. J. Bus. Ethics 2016, 135, 569-585. [CrossRef]

7. Cheng, Z.; Wang, F.; Keung, C.; Bai, Y. Will corporate political connection influence the environmental information disclosure level? based on the panel data of a-shares from listed companies in shanghai stock market. J. Bus. Ethics 2017, 143, 209-221. [CrossRef]

8. Li, L.; Liu, Q.Q.; Tang, D.L.; Xiong, J.C. Media reporting, carbon information disclosure and the cost of equity financing: Evidence from China. Environ. Sci. Pollut. Res. 2017, 24, 9447-9459. [CrossRef] [PubMed]

9. Qian, W.; Schaltegger, S. Revisiting carbon disclosure and performance: Legitimacy and management views. Br. Account. Rev. 2017, 49, 365-379. [CrossRef]

10. Kalu, J.U.; Buang, A.; Aliagha, G.U. Determinants of voluntary carbon disclosure in the corporate real estate sector of Malaysia. J. Environ. Manag. 2016, 182, 519-524. [CrossRef] [PubMed]

11. Grauel, J.; Gotthardt, D. The relevance of national contexts for carbon disclosure decisions of stock-listed companies: A multilevel analysis. J. Clean. Prod. 2016, 133, 1204-1217. [CrossRef]

12. Matsumura, E.M.; Prakash, R.; Vera-Munoz, S.C. Firm-value effects of carbon emissions and carbon disclosures. Account. Rev. 2014, 89, 695-724. [CrossRef]

13. Kostova, T.; Zaheer, S. Organizational legitimacy under conditions of complexity: The case of the multinational enterprise. Acad. Manag. Rev. 1999, 24, 64-81. [CrossRef]

14. Braam, G.J.M.; Weerd, L.U.D.; Hauck, M.; Huijbregts, M.A.J. Determinants of corporate environmental reporting: The importance of environmental performance and assurance. J. Clean. Prod. 2016, 129, 724-734. [CrossRef]

15. Girma, S.; Gong, Y.; Görg, H. What determines innovation activity in Chinese state-owned enterprises? The role of foreign direct investment. World Dev. 2009, 37, 866-873. [CrossRef]

16. Peng, K.; Xu, T.T.; Ning, G.F. Impact of corporate governance on environmental information disclosure-Evidence from China. Appl. Mech. Mater. 2014, 448, 4314-4318. [CrossRef]

17. Fodio, M.I.; Oba, V.C. Boards' gender mix and extent of environmental responsibility information disclosure in Nigeria: An empirical study. Eur. J. Bus. Manag. 2012, 4, 163-169.

18. Kolk, A.; Levy, D.; Pinkse, J. Corporate responses in an emerging climate regime: The institutionalization and commensuration of carbon disclosure. Eur. Account. Rev. 2008, 17, 719-745. [CrossRef]

19. Liu, X.; Anbumozhi, V. Determinant factors of corporate environmental information disclosure: An empirical study of Chinese listed companies. J. Clean. Prod. 2009, 17, 593-600. [CrossRef]

20. Luo, X.; Du, S. Exploring the relationship between corporate social responsibility and firm innovation. Mark. Lett. 2015, 26, 703-714. [CrossRef]

21. Wong, P.K.; Ho, Y.P.; Autio, E. Entrepreneurship, innovation and economic growth: Evidence from GEM data. Small Bus. Econ. 2005, 24, 335-350. [CrossRef]

22. Chan, K.; Menkveld, A.J.; Yang, Z. Information asymmetry and asset prices: Evidence from the China foreign share discount. J. Financ. 2008, 63, 159-196. [CrossRef]

23. Huayu, S.; Ning, X.; Jun, Z. Customer-based concentration and firm innovation. Asia-Pac. J. Financ. Stud. 2018, 47, 248-279.

24. Ak, B.K.; Patatoukas, P.N. Customer-base concentration and inventory efficiencies: Evidence from the manufacturing sector. Prod. Oper. Manag. 2016, 25, 258-272. [CrossRef]

(C) 2019 by the authors. Licensee MDPI, Basel, Switzerland. This article is an open access article distributed under the terms and conditions of the Creative Commons Attribution (CC BY) license (http://creativecommons.org/licenses/by/4.0/). 